特集：イメージング

\title{
MALDIイメージング質量分析は「結晶」が命！
}

\section{Importance of Matrix Crystal Morphology in Imaging Mass Spectrometry}

\author{
新間秀一 \\ Shuichi SHImma \\ 大阪大学大学院工学研究科生命先端工学専攻
}

\section{1.はじめに}

マトリクス支援レーザー脱離イオン化法（MALDI: matrix-assisted laser desorption/ionization）を用いたイメージ ング質量分析（IMS: imaging mass spectrometry）を始めよ うと思う方が，最初に頭を悩ませることの一つは装置の才 ペレーションもさることながら MALDI-IMS 用試料調製で あると思われる。ももちんスペクトル解釈を含むデータ解 析も困難な点の一つであることは言うまでもないが，そこ に到達するまでには安定したデータ取得ができるようにな らなければならない。

「試料前処理なしでIMSできたらいいのに」，「試料前処 理をロボットがやってくれたらいいのに」と心から願う方 も多いと思う。実際，本特集号の著者である木原さん（資 生堂）が扱っている脱離エレクトロスプレーイオン化 （DESI: desorption electro-spray ionization）を用いた前処理 フリーのイオン源や, 田中さん（塩野義製薬）が扱ってい る ImagePrep（Bruker Daltonics社）のようなマトリックス 自動噴霧装置も現在は入手可能にはなっている。しかし, これらがどこのラボで誰がやってもオールマイティーに機 能するというわけではなく, やはりノウハウが必要である 現実に変わりはないと筆者は感じている.

\section{2. マトリックス供給での知られざるトラブル}

これまで蓄積されたノウハウから, 由来組織や測定対象 物質に最適な試料前処理法を予測するツールが近い将来生 まれるかもしれないが, 本稿では現在のノウハウについて 紹介したいと思う. その前に, 既存手法での問題点を明ら かにしておきたい。

MALDI-IMSで必要となるマトリックスを供給するため の既存手法は, 溶液となったマトリックスを直接組織表面 に噴霧することが一般的である.しかし，この方法を試み た経験がある人はマトリックス結晶が組織表面でなかなか 形成されないという経験をしたことがあるかもしれない. もしくは, 試料組織に亀裂が入ってしまい, さらに亀裂に

連絡先：sshimma@bio.eng.osaka-u.ac.jp
沿って組織が収縮しガラス表面がむき出しになることを経 験したことがあるかもしれない。このような試料を測定す ると，ガラス部分からのみシグナルが検出され，一体何の イメージングを行っているのかわからないという結末が 待っている。

以下で紹介するのは，このトラブルを回避するためのマ トリックス供給法のノウハウである。この方法自体は，い ろいろな測定対象に応用でき，いろいろな人が使えるよう になる技術であると思っている，ただし，技術習得のため に指導を受けるほうが効果的であることは事実である．実 際，筆者のラボメンバーはIMSを行うときには必ずマト リックス供給法のトレーニングを受けることになる.

\section{3. マトリックス供給法の工夫}

以上のような多くの人が一度は経験するが，決して論文 には記述されないトラブルを解消する手法が，本稿で紹介 する「二段階マトリックス供給手法（以下，二段階法）」 である ${ }^{1) \sim 3)}$. 図 1 は二段階法の概要と得られる効果につい てまとめられているが，まずは方法論について解説した い.

二段階法では，マトリックス粉末の蒸着とマトリックス 溶液の噴霧を組み合わせている。一段階目で，マトリック スの真空蒸着を行う。この工程は, 試料組織表面に結晶成 長のための微小な結晶核を供給することに相当する。真空 蒸着でマトリックスにかける温度は，用いるマトリックス の融点に設定すればよい。したがって， $\alpha$-シアノ-4-ヒド ロキシけい皮酸（ $\alpha$-CHCA）の場合は $250^{\circ} \mathrm{C}$ となる.

二段階目では組織表面を蒸着後, 大気中に取り出し一段 階目と同じマトリックスの溶液を噴霧する。筆者は通常エ アブラシを用いて噴霧している。原理的には，蒸着と噴霧 を組み合わせればいいため, マトリックス自動噴霧装置も 使うことが可能である．噴霧を行うとすでに組織表面に供 給されている結晶核により，一瞬にして組織表面にマト リックス結晶が成長する。

図 1 に示すように噴霧により得られる結晶は，非常に微 細で密になるため組織保護膜の効果も得られる。すなわち 二段階法では組織の収縮は，既存法と比較してほとんど観 


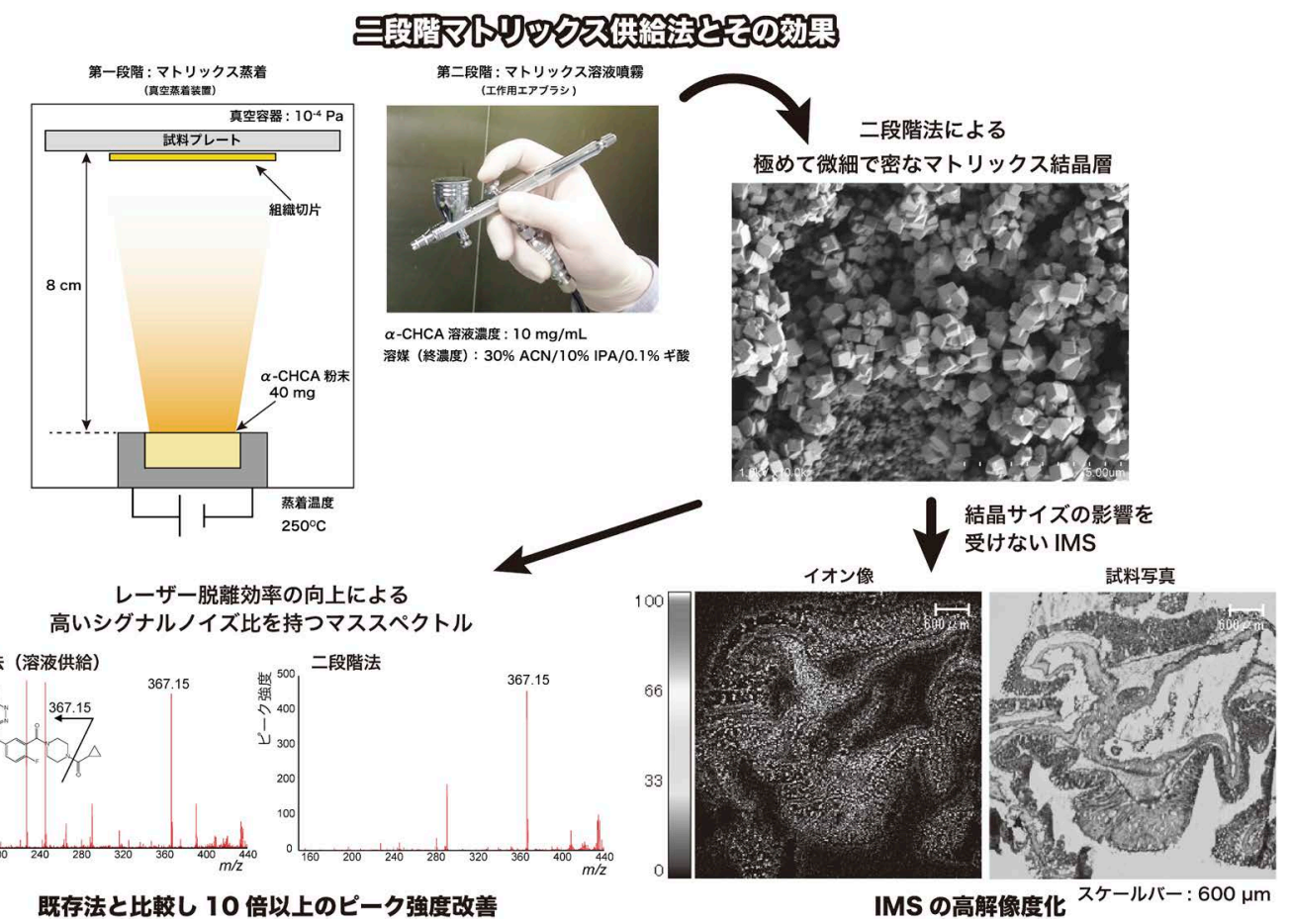

図1.二段階マトリックス法概要と得られる効果について.

察されないという特徵がある。また, 二段階法ではIMS でしばしば問題になる分子の移動（われわれはモレキュ ラーマイグレーション“molecular migration”と呼んでい る）が非常に少ないことも確認している。この理由につい ては，筆者自身で詳細に原因を調べたいと考えている，以 下では二段階法における他の顕著な効果として, ピーク強 度の増大と高解像度IMSへの貢献について触れておきた い.

\section{4. 微細結晶によるピーク強度の増大}

MALDI を普段扱っている研究者からすれば，マトリッ クス結晶の大きさは得られるマススペクトルのシグナルノ イズ比（S/N）に大きく影響することは周知の事実であ る. 既存の MALDIで微細なマトリックス結晶を得る方法 の一つとして, 金属プレート上にアセトンなどを溶媒とし た $\alpha$-CHCA の薄膜を作り，その膜上にマトリックスとサン プルの混合物をスポットするThin layer法がよく知られて いる ${ }^{4)}$.

二段階法はこの原理を組織表面上で実現した手法である といえる。すでに述べたとおり，あらかじめ供給された微 細なマトリックス結晶核の存在により, スプレー噴霧後に 得られる結晶は図 1 に示すとおり非常に微細である. 得ら れる結晶が微細であることで, 組織上のマトリックス表面 積が増大しレーザー照射による脱離の効率が向上すると考 えられる。これが通常の方法に比べてピーク強度が増大す る要因と考えられる。図 1 には，オラパリブと呼ばれる薬 物を投与したマウス肝臓上で得たプロダクトイオンスペク トルを示しており, 既存法と比較しプロダクトイオン強度 が10倍以上向上している。このような組織上でのイオン
強度の増大と $S / N$ の改善により高いコントラストをもつ鮮 明なイオン分布像を得ることができるようになる.

\section{5. 微細結晶による高解像度 IMS}

本特集号で平さん（福井県立大学）が述べているよう に，マトリックス結晶の大きさは高解像度IMS を行う際 に大きな足かせとなる。これを回避するために無機マト リックスの利用が報告されている。この技術同様, MALDIにおいても微細なマトリックス結晶が得られれば 非常に微細な構造まで可視化が可能になる。筆者のグルー プでは，二段階法を用いたイオン強度増加と同時に，マト リックス結晶の影響なくルーチンで $20 \mu \mathrm{m}$ 以下（最高 $5 \mu \mathrm{m}$ ）で低分子化合物のIMS を行えるようになっている.

「MALDI では高解像度の測定や低分子化合物の測定はマ トリックスの影響により難しい」という話をよく聞くが, 二段階法を用いて MS/MSでイメージングを行えばMALDI であっても高感度・高解像度で低分子化合物のIMSが可 能である。むしろ「MALDIであるから可能になることも 多い」と筆者は感じている.

\section{6. ま と め}

現時点では, $\alpha$-CHCA とシナピン酸で二段階法の効果を 確認している。一方, IMSで頻繁に用いられる他のマト リックスである2,5-ジヒドロキシ安息香酸 (2,5-DHB) や 9-アミノアクリジン（9-AA）の場合は, 蒸着で結晶核を 供給したとしても噴霧時に核が溶解してしまうため, 二段 階法を適用することができていない.しかし, 例えば一段 階目で $\alpha$-CHCAの蒸着, 二段階目で2,5-DHB噴霧で 2,5DHBの結晶サイズを変えることが可能であることを確認 
している（ $\alpha$-CHCAおよび9-AAの組み合わせはイオン化 サプレッションが起きるため不可)。このように，溶解度 が高いマトリックスでは二段階法を直接使うことができな いが，蒸着で用いるマトリックスを工夫することでさらに 改善するかもしれない.

一方，2,5-DHBや9-AAでは蒸着後に水蒸気やアルコー 儿蒸気中に静置することで再結晶化を促しピーク強度を改 善する手法も報告されている ${ }^{5)}$.このように測定対象抢よ び用いるマトリックスに応じてさまざまな前処理方法を試
みることで,「みたいものがみえる」技術にまた一歩近づ くと思う.

\section{文献}

1) S. Shimma, Mass Spectrom. Lett., 6, 21 (2015).

2) S. Shimma and Y. Sugiura, Mass Spectrom., 3, S0029 (2014).

3) S. Shimma et al., J. Mass Spectrom., 48, 1285 (2013).

4) D. Fenyo et al., J. Vis. Exp., 3, 192 (2007).

5) W. Bouschen et al., Rapid Commun. Mass Spectrom., 24, 355 (2010). 